\title{
Armenian Security and U.S. Foreign Policy in the South Caucasus
}

\author{
Col. Dr. Hayk Kotanjian *
}

\section{Key Points ${ }^{1}$}

The South Caucasus is becoming one of the most dynamic geostrategic regions of the globe, reflecting in particular the long-term interests of U.S. foreign policy in the vast region of Central Eurasia. In this essay, I will seek to share some reflections both with American and Armenian academics on the importance of the Armenian factor in establishing a comprehensive security architecture in the South Caucasus, as well as in promoting economic progress and democracy in this region. I will introduce some specifics of the Armenian case, particularly regarding the active involvement of the Armenian Diaspora in the political life of the United States, as well as the importance of the Republic of Armenia in promoting regional security and democracy in the South Caucasus, a process which is either bridging or colliding with the foreign policy interests of the U.S., the EU and Russia, as well as those of the regional actors in Central Eurasia. The notions presented here on the restructuring of the security architecture in the South Caucasus should be of interest also for policy makers and decision-making circles.

\section{Introduction}

Thirteen years have passed since the Republic of Armenia regained its independence. It is not a sufficiently long period of time to afford an opportunity for a comprehensive evaluation of results and for comparing opportunities, expectations, and achievements. In such a brief discussion it is virtually impossible to do justice to all aspects of the intricate transitional processes taking place in the South Caucasus, and specifically in Armenia. Nevertheless, I will try to briefly review the dynamics of the situation, assess some features of Armenian reality, and draw certain historical parallels with the neighboring nations of the Caucasian region. In addition, I will try to assess the dynamics of these fledging low-intensity democracies within the foreign policy frame of the main actors in the region. Considering the ideas on the restructuring of the security architecture in the South Caucasus to be a goal of this paper, I hope that some of my concluding suggestions could attract the interests of the professionals working on the

* Colonel Dr. Hayk Kotanjian is a Counterterrorism Fellow at the National Defense UniversitySchool of National Security Executive Education (NDU-SNSEE). In parallel with his fellowship, he directs a research program at the NDU-Institute for National Security Studies (INSS) on the establishment of the Institute for National Strategic Studies in Armenia. He has published widely on foreign policy and the security climate in the South Caucasus.

1 NOTE: The views expressed in this paper are those of the author, and do not reflect the official policy or positions of the governmental institutions of the Republic of Armenia. 
prospects of U.S. foreign policy in this region.

Once the Soviet Union disintegrated, Armenia found itself in a most precarious situation, as compared with other post-Soviet newly independent states. Problems common to all these states, caused by the collapse of the centralized economy, were exacerbated in Armenia by the consequences of the earthquake of 1988, the conflict with neighboring Azerbaijan, and by an economic blockade and a large influx of refugees. Under these circumstances, the country's leadership initiated a radical restructuring of the economy and a process of privatization.

The United States recognized the independence of all the former Soviet republics by the end of 1991, including the South Caucasus states of Armenia, Azerbaijan, and Georgia. The United States has fostered these states' ties with the West, including membership in the Organization for Security and Cooperation in Europe (OSCE) and NATO's Partnership for Peace (PfP), in part to end the dependence of these states on Russia for trade, security, and other relations. The United States pursued close ties with Armenia to encourage its democratization and because of concerns on the part of Armenian-Americans and others over its fate. Prior to his recent resignation as Georgia's President, Eduard Shevardnadze also had close contacts with the United States. Elsewhere in the region, growing U.S. private investment in Azerbaijan's oil resources strengthened U.S. interests there. The United States has been active in diplomatic efforts to end conflicts in the region, many of which remain unresolved.

Faced with calls in Congress and elsewhere, Washington developed a policy for assisting the Eurasian states of the former Soviet Union. President George Bush proposed the Freedom Support Act in early 1992, which was signed into law that year, while P.L. 102-511 authorized funds for the Eurasian states for humanitarian needs, democratization, creation of market economies, trade and investment, and other purposes. Section 907 of the Freedom Support Act largely prohibited U.S. government-togovernment aid to Azerbaijan until it ceased blockades and other offensive uses of force against Armenia. This provision for Azerbaijan was partly altered over the years to permit humanitarian and democratization aid, border security and customs support to promote non-proliferation of weaponry, etc. To balance this prohibition of aid for Azerbaijan in the field of defense cooperation, the American government administratively banned defense cooperation with Armenia as well.

In December 2001, Congress approved foreign appropriations for FY2002 (P.L.107-115) that granted the President authority to waive Section 907, renewable each year under certain conditions. President Bush exercised the waiver on 25 January 2002 and 17 January 2003.

The current Bush Administration has appealed for a national security waiver of the prohibition on aid to Azerbaijan, in consideration of Azerbaijan's assistance to the in- 
ternational coalition to combat terrorism. ${ }^{2}$

\section{Some Geostrategic Specifics of the Armenian Diaspora and the Armenian Nation-State}

The major and most often mentioned event in the modern political history of the Armenians is the catastrophic geopolitical change in their historical homeland during World War I. During that time, Ottoman Turkey's regime - in furtherance of its brutal policy of ethnic cleansing in Asia Minor of the indigenous Armenians-decided that the deported Armenians would not be returned to their homes. In the 1920s, the survivors finally realized that the deportations had been only the prelude to the permanent exile of the Armenian people from their ancestral homeland. ${ }^{3}$ These were the historical specifics of the military-political conditions that established a new geopolitical configuration of the Armenian Diaspora, which is now dispersed worldwide.

Organizations of the Armenian Diaspora over the decades have acted with the hope that the modern democratic Republic of Turkey will eventually distance itself from the catastrophic experience suffered under the Ottomans and follow the meritorious example of the condemnation of Nazi Germany by the Federal Republic of Germany for the Holocaust perpetrated against the Jews.

Nevertheless, it is necessary to underscore the objective reality that in the Armenian Diaspora today, the memory of the massacres perpetrated by the Ottoman Empire has come to occupy a central place in the minds of 10 million Armenians living in more than fifty countries of the world.

Consequently, Armenians living in the Republic of Armenia currently represent about one-third of the entire Armenian population of the world. ${ }^{4}$ Following the establishment of an independent nation-state, interaction between Armenia and the Diaspora, limited earlier both ideologically and politically by the Soviet regime, became one of the main geostrategic factors facilitating political, economic, cultural, and informational cooperation between the newly-independent Armenian state and the world.

As an independent state subject to international law, the Republic of Armenia faced new challenges, which were not necessarily and immediately perceived by the Diaspora, since such a historical development was rather unexpected. Only thirteen years ago these two components of the Armenian nation were given unlimited opportunities

2 A helpful recent discussion of the security environment in the South Caucasus in general is available in the form of a transcript of an interview with the European Parliament's rapporteur for the South Caucasus, Per Gahrton. The interview was done on 12 February 2004, and is available on the web site of Radio Free Europe/Radio Liberty (RFE/RL), at http:/www. rferl.org.

3 See "From the Silence of a Diaspora," at http://www.genocide.am/adalian/silen.htm. There are ongoing negotiations among selected representatives of the NGOs from the Republic of Armenia, Republic of Turkey, and the Armenian Diaspora.

4 See "The Armenians in the World" (in Russian), at http:/www.iatp.am/economics/migr/ hayga-r97.html; "Golos Armenii” (in Russian), Armenian Daily, 22 August 1996, 92. 
to decide for themselves which areas and what forms of mutual relations would be most beneficial. Both parties have made concerted efforts to meet each other halfway. However, much more is yet to be done. Along with the desire to move and act in concert in political and social fields, many kinds of moral, psychological, historical, and social issues and aspirations have surfaced and have even increased in prominence.

The Armenian community in the U.S. is one of the most socially advanced elements of the Diaspora, and consists of approximately one million Americans devoted to the Armenian Apostolic, the Armenian Catholic, and the Armenian Protestant Churches, as well as associated with other NGOs. Generally speaking, lobbying at the community level by ethnic minorities worldwide serves the needs of the natural, albeit complex, process through which they assert themselves politically.

The Armenian lobbying experience has shown that the issues confronting the Diaspora are beyond the narrow boundaries of a community, because the goal is much broader. In fact, it is nationwide. At the same time, any initiatives, however important and responsibly undertaken, should never endanger the interests of either the U.S. or the newly independent republic of Armenia and the Armenians living there. The programs encourage greater Armenian-American participation in the American democratic process and the civic and economic development of Armenia.

Current developments in Armenia are at the center of the Armenian Diaspora's attention; thus, separate Armenian non-governmental structures constantly work with the U.S. Congress and Administration. Among the many successes of Armenian NGOs is leadership in advocating formation of the Congressional Caucus on Armenian Issues (in 2004 totaling 128 Members of the U.S. Congress). ${ }^{5}$

The Diaspora became a factor in actively facilitating the promotion of a culture of Western liberalism and democracy during the transition of Armenia from the limitations of the Soviet one-party system. In the first years of independence, the traditional Armenian political parties (Armenian Revolutionary Federation, Liberal Democratic Party, and Armenian Social Democratic Party) returned to Armenia and reorganized. They invigorated the national spirit and brought about liberalization and democratic values, which, at that time, became a foundation of and cause for the free "competition" of political and civic associations. This has been a remarkable phenomenon that is accounted for by the newly won independence and the consequent establishment of democratic principles and fundamental freedoms in the Republic of Armenia.

The Armenian Diaspora exists factually as a global network of about 10 million, politically active, prosperous, and well-educated Armenians who are closely integrated into American and European economic, financial, and political life. It has become an effective venue for the promotion of American-Armenian, Franco-Armenian, RussoArmenian, Armenian-Arab, and Armenian-Persian relationships (among others), and bilateral cooperation in favor of mutual national strategic interests within the entire geopolitical scope of this relatively small but dynamic and well-organized world-wide community (within and beyond the regional boundaries of the South Caucasus).

${ }^{5}$ See http://www.panarmenian.net/news/rus/?task=society\&id=9782\&date=2004-02-16. 


\section{Developing the Democratic Rule of Law in Armenia: Progress and Difficulties}

As a result of the elections conducted on 20 May 1991, which were the first democratic elections held on a competitive basis in the history of the Soviet Union, the Communist Party lost power. This served as a catalyst for initiating the establishment of a multiparty system in Armenia. The Armenian National Movement (AMN) came to power.

In the previous year, the 23 August 1990 Declaration of the Supreme Council had already marked the beginning of democratic reforms. The newly elected Parliament (formed before the declaration of Armenia's independence) set out immediately to form a legislative basis for societal democratization. The laws on ownership and on the foundations of privatization in the Republic of Armenia (adopted respectively on 31 October 1990 and 13 December 1991) provided the legal basis for a transition from state monopoly to diverse forms of ownership of the means of production. The transition to pluralism and a multi-party system was effected by the 26 February 1991 law on non-governmental political organizations. Freedom of speech and of information was secured by the law on the press and other mass media, passed on 8 October 1991. On 17 June 1991, the law on freedom of conscience and religious organizations was adopted in order to safeguard the freedom of belief. The democratic legal norms stipulated by these and other laws were also reflected in and advanced further by the new republic's constitution, ratified on 5 July 1995. In 1996, the National Assembly adopted the laws on local self-government and on the election of local government, which provided the legal groundwork for the elections of local governments that took place on November 10 of that year. Also in November 1996, the law on non-governmental organizations, which was a major contribution towards the building of a civil society, went into effect.

At present, many of the democratic norms that underlie the constitution and the laws adopted within the past thirteen years need to evolve further. This is also attested by the resolution on Armenia's accession, passed by the Parliamentary Assembly of the Council of Europe. The resolution calls upon Armenia to meet certain commitments, including acceding to European conventions and adhering to national legislation of European democratic standards. ${ }^{6}$ Currently laws are being drafted that will be in harmony with those of European democracies. To expedite the process, specialists from the Council of Europe are providing expert opinion and advice. Work on constitutional amendments, underway already for several years, has come to an end, and the package of amendments is ready to be discussed in the National Assembly.

All these developments, in turn, are among the main guarantees for the protection of human rights. Through the 23 August 1990 Declaration, Armenia in fact adopted a

${ }^{6}$ The Republic of Armenia became a member of the Council of Europe (COE) on 25 January 2001. As a political entity, the COE promotes political stability, economic and social progress, democracy, and human rights protection in Europe. The unified standards and approaches have been designed to address these issues and to ensure progress in that field. 
new value system, reinforcing its commitment to the principles of democracy and human rights. After independence, the Republic of Armenia as sovereign entity acceded to and joined the major human rights conventions and agreements, as well as initiated the work on reforming domestic legislation in this sphere. Further, the second chapter of the Republic of Armenia's Constitution reinforced basic human rights and freedoms.

Despite the already mentioned improvement of electoral legislation, different types of violations were observed both by local and international observers during the 1995, 1996, 1998, and partially the 2003 presidential and parliamentary elections. Many human rights groups criticized detentions that took place during the latter election as politically motivated, although the government alleged that the detainees had taken part in riots. OSCE and PACE observers termed the campaign vigorous and largely peaceful, but concluded that the election did not meet international standards for a free and fair race, because of "widespread" ballot box stuffing, a lack of transparency in votecounting, and other "serious" irregularities.

It is important to compare the status of human rights in Armenia with the neighboring countries of the South Caucasus. As a reliable source for a comprehensive assessment of the issue, I have relied on the "Annual Survey of Political Rights and Civil Liberties," issued by a prominent American NGO, Freedom House, which has been monitoring freedom and advocating democracy in the world since the early 1970s. ${ }^{8}$ According to this independent group of experts, Armenia and Georgia in 2003 were described as "partly free" states, while Azerbaijan was assessed as a "not free" country. ${ }^{9}$

\section{The Democratization of State Governance and Local Self-Government: Achievements and Challenges}

The citizens of Armenia exercise their power through the bodies of state governance and local self-government. The formation of these bodies, resting on a clear-cut division of their powers, functions, and responsibilities, provides a foundation for building a developing and prosperous country.

The system of state power is an integral part of the Armenian legislative sphere, of state governance bodies, and of public service, through which principal state functions are carried out and the problems facing the country are solved. The state governance system in independent Armenia includes executive bodies; the government of the Republic of Armenia, comprised of the Prime Minister and Cabinet Ministers, exercises executive powers. In accordance with the Armenian Constitution, the president of the

7 See also CRS Report RS20812, Armenia Update.

${ }^{8}$ Founded more than sixty years ago by Eleanor Roosevelt and other Americans concerned with mounting threats to peace and democracy, Freedom House today is a leading advocate of the world's young democracies, which are coping with the legacies of dictatorship and political repression.

9 See "Freedom in the World 2004," Table of Independent Countries Comparative Measures of Freedom, at http://www.freedomhouse.org/research/freeworld/2004/essay2004.pdf. 
Republic of Armenia is the guarantor of the nation's independence, territorial integrity, and security.

In my view, the existing state of the governance system in Armenia is, in more ways than one, out of line with present day requirements and urgently needs to be reformed. State governance inefficiencies result from the well-known "diseases" of weak central powers. These are, in particular, a lack of official strategy where implementation is concerned, but also a lack of mechanisms for securing general access to information and its exchange between the branches of government.

Furthermore, duplication of functions and obscurity of instructions at various levels of power, the lack of clear-cut goals and priorities, and no sense of purposefulness significantly reduce state governance effectiveness. Very often the general public has no understanding as to the purpose and necessity of decisions made at various levels of the government. This is the result of a lack of transparency in the authorities' activities and due to their failure to inform the public in advance of the actions they intend to take. At present, a strategy for the formation of an efficient state governance system is virtually non-existent. Such a strategy should provide a foundation for structural and functional reforms and for the improvement of public services.

The processes surrounding the development of a market economy, the establishment of new political and social infrastructures, and the transformation of new social values in Central and Eastern Europe and the former USSR, including Armenia, created an environment conducive to corruption. In terms of its prevalence, corruption can and does exist on personal, institutional, and system-wide levels.

Unfortunately, corruption in Armenia currently has spread to all spheres of life, and has taken on all forms, i.e., it bears the danger of acquiring systemic prevalence. At the same time, it is interesting to study the results of a research survey conducted under the framework of the Caucasian Bureau of the Institutional Reforms of the Informal Sector program, whereby investigators determined that "the corruption level in Armenia is lower than that in other CIS countries and corruption is not systematized. The old system of corruption has been eliminated and a new one has not been created yet."

However, the researchers consider this situation to be less favorable than the above statement would indicate, since the corruption that does exist is unpredictable. Other sources - for instance, Transparency International ${ }^{10}$ — perceived corruption in Armenia as rather high, scoring it at 2.5 on a scale of 0 (highly corrupt) to 10 (highly clean). To gain an impression of the broader regional situation in the South Caucasus countries, we can introduce the figures given in the same assessments for Azerbaijan (2.0) and Georgia (2.4). ${ }^{11}$

${ }^{10}$ Transparency International is the international non-governmental organization devoted to combating corruption by bringing civil society, business, and governments together in a powerful global coalition; see http://www.transparency.org/about_ti/index.html.

${ }^{11} \mathrm{See}$ Global Corruption, at http://www.globalcorruptionreport.org/download/gcr2003/ 24_Data_and_research.pdf. 
In short, while the level of corruption in Armenia is high, it is the lowest among the countries of the South Caucasus (albeit by a narrow margin). According to the research of Transparency International, the highest level of corruption is found in Azerbaijan.

The recent resignation of Georgian President Eduard Shevardnadze under public pressure has underlined the degree of anger of the Georgian people with the intolerable level of corruption throughout their government and society. The newly elected Georgian President Mikhail Saakashvili, speaking in Europe in January 2004 at the invitation of Transparency International, described corruption in Georgia as the greatest challenge facing his country. ${ }^{12}$

\section{Regional Conflicts: "Securitization" of Caucasian States and the Limitation of Democracy Promotion}

Some observers lament that ethnic conflicts have kept the South Caucasus states from fully partaking in peace, stability, and economic development for over a decade since the Soviet collapse. The countries are faced with on-going budgetary burdens of arms races and caring for refugees and displaced persons. Other costs of ethnic conflict include threats to bordering states of widening conflict, and the limited ability of the region or outside states to fully exploit energy resources or trade and transport networks. U.S. and international efforts to foster peace and the continued independence of the South Caucasus states face daunting challenges. The region has been the most unstable part of the former Soviet Union in terms of the numbers, intensity, and length of its ethnic and civil conflicts. The ruling nationalities in the three states are culturally rather insular, and harbor various grievances against each other. This is particularly the case between Armenia and Azerbaijan, where discord has led to the virtually complete displacement of ethnic Armenians from Azerbaijan and vice-versa.

Looking at the big picture of the regional dynamics of democracy, we can state that the nation-states of Armenia, Azerbaijan, and Georgia, currently oriented to the security provisions of conflict threats, are lagging in democracy promotion, and not only in the case of the redistribution of their budgets in favor of army and police force enhancement. By prioritizing the internal policies on the mobilization of national resources predominantly toward security needs, these states are limiting the level of societal diversity of their national life as a whole, specifically in the promotion of a legally institutionalized democracy and liberal economy, both in the national and international arenas.

These kinds of limitations are, in principle, harming the whole process of legal, political, and economic reform, reducing their national and transnational scope and intensity and, as a result, their social effectiveness. The lack of transparency in political, administrative, and economic life in the South Caucasus, along with the high level of corruption, is explained away by invoking the limitations implied by the priority given

${ }^{12}$ See "Yahoo Nyheder, Danmark" news, Thursday, 29 January 2004, at http://dk.news.yahoo. com/040129/33/30hh0.html. 
to national security interests. This kind of "securitization" of national policy, justified by the existence of regional conflicts, is contributing to bureaucratic obstacles to attempts to establish a more genuine democracy by the fledging elements of the weak civil societies in Armenia, Azerbaijan, and Georgia, specifically by their civilian NGOs and independent mass media.

In conclusion, we can say that the real situation as concerns democracy, the absence of a clear vision, and the strategy for democracy promotion, along with the securitization of the economies and of social life as a whole, as well as the existing deviations from the norms and standards of democratic governance in the each of the South Caucasus countries, allows us to assess them as "Low-Intensity Democracies." "13 By this is meant that the intensive promotion of democracy and economic progress in these countries needs to be more specifically elaborated through their engagement in the system of integrative processes and programs encouraged by the more intensively democratic international environment.

\section{Armenia's Security Cooperation: The Strategic Context of International Orientations}

First, let us survey the framework and the dynamics of Armenia's security cooperation with the primary partners among the Euro-Atlantic and CIS countries. In such a context, the Republic of Armenia does have a long-demonstrated interest in cooperating with NATO. The Armenian armed forces began participating in the NATO Partnership for Peace (PfP) program soon after the initiative was launched in 1994. NATO and the three countries of the South Caucasus are cooperating on a range of issues, including high-tech scientific collaboration, English language training, defense education at the NATO institutions, and civil emergency planning. Armenia has benefited greatly from civil emergency planning activities and from NATO's Science Program. One project that NATO is helping to finance, which is of particular importance to Armenia, aims to link up the information systems of its institutes for seismological analysis with those of institutes in Greece, Italy, and the U.K.

The Armenian armed forces are intensifying their participation in PfP-based exercises. Armenian Special Forces troops, in exercise Cooperative Best Effort 2002 in Tbilisi, Georgia (17-28 June 2002), cooperated with colleagues from the following NATO countries: Canada, Greece, Hungary, Turkey, the United Kingdom, and the United States. The Partner Nations involved in CBE 2002 with Armenia were: Austria, Azerbaijan, Bulgaria, Georgia, Lithuania, Moldova, Romania, and Ukraine.

June 2003 was the first time that Armenia hosted a NATO/PfP exercise, which brought together approximately 400 troops from 19 different NATO and Partner countries. Participants came from Armenia, Austria, Bulgaria, Canada, Georgia, Greece, Hungary, Italy, Lithuania, Moldova, Poland, Romania, Russia, Slovakia, the

${ }^{13}$ See Steve Smith, "American Democracy Promotion," in US Democracy Promotion: Critical Questions (Oxford: Oxford University Press, 2000), 72-74. 
Former Yugoslav Republic of Macedonia, Turkey, the United Kingdom, the United States, and Uzbekistan. It is important to mention that, with the facilitation of Armenia, this event was the first time that Russia participated in this type of military exercise, with staff officers and an infantry squad integrated into the exercise's multinational force structure. ${ }^{14}$

It is also important to mention that this NATO/PfP exercise hosted by Yerevan created a good opportunity for both Armenian and Turkish troops to cooperate for the first time on the soil of the independent Armenian state. The aim of this exercise in Armenia was to improve land force effectiveness in the field by making NATO and Partner contributors work together to develop better understanding and interoperability, and this goal was reached comprehensively.

Under the guidance of NATO (specifically, Greece and the U.S.), Armenia in 2004 took the initial step of participation in international peacekeeping operations. A platoon of thirty-four Armenian servicemen serving on a contractual basis is part of a special Armenian peacekeeping battalion that has been trained, equipped, and financed by Greece. Recently it has been under the command of a Greek army battalion deployed in Kosovo. Armenian servicemen have had intensive English language courses sponsored by the U.K. and U.S., and are provided with advanced communication means, including satellites. Under the terms of the agreement, the Greek side will also take care of their insurance problems. ${ }^{15}$

The application for membership in the NATO Partnership for Peace Consortium of Defense Academies and Security Studies Institutes recently submitted by the Armenian Ministry of Defense (MOD) should be considered as a step toward long-term intellectual cooperation with the NATO Partners (membership was approved in January 2004). ${ }^{16}$ The Armenian MOD assigned an officer to the Alliance's Partnership Coordination Cell in Mons in 1998. The Armenian Ambassador to the Benelux countries simultaneously serves as the Ambassador to NATO Headquarters. In accordance with recent decisions, Armenia is going to establish a diplomatic mission to NATO in 2004.

Armenia is also operating as an active member of the Organization for Security and Cooperation in Europe (OSCE), which comprises all the European countries, plus the United States and Canada, fifty-five nations in all. ${ }^{17}$ Hoping to be integrated as part of a larger Europe, Armenia is acting as a member of the European Council. This membership is an additional factor functioning in favor of the alignment of the Armenian legal-political system with the standards of the European Union. Armenia's official

${ }^{14}$ See "NATO Update," Cooperative Best Effort 2003, at http://www.nato.int/docu/update/ 2003/06-june/e0616a.htm.

${ }^{15}$ See $A Z G$ Daily, No. 24, 13 February 2004, at http://www.azg.am/start.pl?lang=EN\&num= 2004021300.

${ }^{16}$ See NATO Partnership for Peace Consortium of Defense Academies and Security Studies Institutes, Armenia, at http://www.pfpconsortium.org/.

${ }^{17}$ In addition, its cooperation partners are Japan, Korea, and Thailand as well as the Mediterranean countries Algeria, Egypt, Israel, Jordan, Morocco, and Tunisia. 
policy is proclaimed as "progressive integration into EU models and standards." Currently Armenia, as well as Azerbaijan and Georgia, are cooperating with the EU on becoming, in the mid-term, future aspirants for membership. ${ }^{18}$

American-Armenian security cooperation is going on under the political umbrella of bilateral intergovernmental "Security Dialog" since 1998. In July 2000, the leaders of the US and Armenia Defense Departments signed the Agreement concerning cooperation in the area of counter-proliferation of weapons of mass destruction.

Since 2002, the Armenian and American armed forces have been partners not only under the rubric of NATO/PfP but also in the dimension of bilateral military cooperation. The mechanism of bilateral defense consultations led by the U.S. Assistant Secretary of Defense and the Armenian Deputy Minister of Defense was established during that period. The programs of FMF as well as IMET cooperation have been launched, and are planned and controlled in one process.

Last year, with the assistance of the Pentagon as well as of the Armenian-American community, the Armenian Humanitarian Demining Center was established. The new chapter of U.S.-Armenian defense cooperation is concerned with the participation of Armenia in coalition forces operating in Iraq. The Armenian Ministry of Defense sent to Iraq a platoon consisting of a column of thirty trucks with specially trained drivers, as well as sappers, and doctors trained for medical humanitarian assistance.

Simultaneously, Armenia is bearing her responsibilities as a member of the NIS Collective Security Organization (SCO), operating as a strategic partner of the Russian Federation.

Summarizing these symptomatic facts of Armenia's multi-polar orientation, some experts would wonder about the peculiarities of such a specific geostrategic configuration, particularly the balance of her security-defense orientation. For example, some analysts from Moscow ${ }^{19}$ were frustrated with the balanced promotion of not only Armenian-Russian but also Armenian-U.S., as well as Armenian-NATO (PfP) cooperation. Similar preoccupations, though less common, are also voiced by American experts. This kind of anxiety, however, seems to be a remnant of Cold War psychology.

In my replies to such criticism, I have explained earlier to my colleagues that Russia is promoting her cooperation with NATO more intensively and widely than Armenia, joining the NATO-Russia Standing Council at the Rome NATO-Russia Summit, and by opening the NATO Office in Moscow. These steps do not hinder the security responsibilities of Russia concerning her partners from the SCO, and specifically with Armenia.

In my view, the Strategic Dialogue between the leaders of the U.S. and Russia is the best venue for bringing together the strategic security interests not only of the U.S. and Russia but also of their partners and friends, such as Armenia, Azerbaijan, and

${ }^{18}$ See "The EU's relations with Armenia," at http://europa.eu.int/comm/external_relations/ armenia/intro/.

${ }^{19}$ In this case I refer to the Russian daily newspaper Nezavisimaya gazeta, which is well known for its politically biased articles. 


\section{Georgia. $^{20}$}

In this supranational context of the security partnership, Armenia is prioritizing methods of synergizing Armenian-U.S., Armenian-Russian, as well as ArmenianNATO security and defense cooperation. ${ }^{21}$ The special importance of this strategic balance's priority is explained by the existence and active influence of the Armenian Diaspora on the political life of Armenia as well as on that of the countries in which they reside (Russia, U.S., France, etc).

\section{The Regional Dynamics of Democracy Promotion and Economic Progress: Strategic Assessments of the American Ambassadors (CSIS Outreach)}

It is appropriate here to observe the situational dynamics and possible prospects in the South Caucasus as described by the former U.S. Ambassadors in each of the countries of this region. In their memo, published via the Center of Strategic and International Studies, Harry Gilmore (former U.S. Ambassador to Armenia), Richard Kauzlarich (former U.S. Ambassador to Azerbaijan), and Kenneth Yalowitz (former U.S. Ambassador to Georgia) outlined the main problems in the region, along with their proposed solutions. They considered these issues in the light of U.S. foreign policy interests.

The authors questioned why these three small countries, weakened by ethnic conflicts, corruption, and the inability to cooperate on a regional basis to promote economic growth, should be so important to the U.S. More than one million ArmenianAmericans care deeply about Armenia and the South Caucasus, and lobby Congress and the White House to ensure that the U.S. provides strong material and political support to Armenia. But there is much more to U.S. interests in the region than that.

These countries can play more valuable roles in the war against terrorism. All three have strongly condemned the September 11 terrorist attacks and offered their support and assistance. Azerbaijan, as a secular Muslim country, can play a particularly important part in the public diplomatic struggle we must wage to win minds in the Muslim world. Armenia, with her worldwide Diaspora population, can participate in the

${ }^{20}$ See Hayk Kotangian, "In Agenda: Multi-Polar and Complementary Defense Policy," Golos Armenii, 16 November 2002.

${ }^{21}$ See, for instance, this excerpt from the "Strategic Assessment of Central Eurasia," a research report published by CACI and the Atlantic Council of the U.S. done at the request of the U.S. Joint Chiefs of Staff in February 2001:

"Armenia has the strongest army in the South Caucasus, and unit for unit, in the CIS, benefiting from a solid national will, combat experience and good equipment. Its troop strength numbered 44,000 by mid 2000." (59); "Karabakh's army of 20-25,000 men is known to be even tougher than Armenia's. Iron discipline and fervent patriotism characterize Karabakh's Armenian people. They also have century-old military tradition: Karabakh gave the Soviet Union three marshals (equal to five-star generals), one five-star admiral and 30 generals" (60-61). Full report at http://www.acus.org/publications/policypapers/international security/Central\%20Eurasia.pdf. 
promotion of mutual American-Armenian national interests in the appropriate regional programs (including or excluding the South Caucasus).

The facilities and infrastructure of all three countries also could be of considerable use as events unfold in this conflict. Opening Armenia's borders with Turkey and Azerbaijan - currently closed due to the Armenian-Azerbaijani dispute regarding Nagorno-Karabakh (a predominantly Armenian populated region which legally seceded from former Soviet Azerbaijan during the collapse of the Soviet Union) — would facilitate over-flights and the use of bases in the region.

Energy issues also are vital. Azerbaijan is rich in oil and gas resources, and is the envisaged starting point for two major pipelines, one for oil and one for gas, that would traverse Georgia and then proceed to Turkey. These pipelines, which now appear to be commercially viable, not only would add important contributions to the world fuel supply; they would also generate badly needed revenues for Azerbaijan and Georgia, and thereby strengthen their sovereignty.

The pivotal location of the South Caucasus also means that weakness and instability in these countries would likely exacerbate the tendencies of outside powers to create spheres of influence or intervene directly. The Nagorno-Karabakh dispute and the internal conflicts in the Georgian regions of Abkhazia and South Ossetia have been the greatest challenges to the survival of these states since their independence.

The American Ambassadors suggested that the United States in its foreign policy must continue to make unmistakably clear to the international community and all regional actors that internal weakness and instability in the South Caucasus will not only invite foreign interference, it will also destroy a critical geostrategic trans-regional infrastructural bridge to Central Asia, create a haven for drug trading and international criminal elements involved in the illicit movement of weapons of mass destruction or their components, and allow for an influx of extremist elements seeking to create an Islamic state in the northern Caucasus regions of Russia and the South Caucasus countries. That is why the optimal way to support stability and democratic advancement in the South Caucasus is through assistance in maintaining the peaceful resolution of regional conflicts in parallel with support for the processes of regional integration.

As the authors say, significant progress has been made in nation building in all three countries in the years since independence (as was mentioned above). But their governmental institutions are fragile and still evolving, and pervasive corruption remains a great threat to the growth of democracy and a market economy. Institutional fragility and corruption have in fact severely weakened public trust in the political leadership in all three states.

These problems are significant and challenging, but remain the responsibility primarily of the three countries concerned. The United States, however, has a strong interest in helping the South Caucasian states become stable, prosperous, and democratic. These authoritative diplomats and experts on Armenia, Azerbaijan, and Georgia recommended four steps toward that end. Although these suggestions were made in 2002, they remain strategically essential. Later in this essay, I will try to extend my own proposals on the advancement of peace, stability, democracy, and prosperity, both 
on the national level and the regional scope of the neighboring nations of Armenia, Azerbaijan, and Georgia.

But before introducing my own suggestions, it is useful to understand the ideas that conclude the ambassadors' memo. We are confident that these measures could be considered as the constructive skeleton of the U.S. foreign policy strategy in the South Caucasus. That is why I cite below the original fragment of the document relating to the comprehensive pursuit of U.S. interests in this region ${ }^{22}$ :

First, we must use the opportunity of our new dialogue with Russia to nail down a common interest and approach to promote independence, stability, and peace in the South Caucasus. Russian encouragement of the Central Asian countries to cooperate with us in Afghanistan is a very positive step, but we need to ensure that we are also on the same wavelength in the South Caucasus. In practical terms this means a genuine Russian willingness to help resolve the festering problems of Abkhazia and South Ossetia within a unified Georgia, to respect Georgia's borders, and to bring Azerbaijan and Armenia to a just solution on Nagorno-Karabakh.

Second, regional cooperation among the three countries has been blocked largely by Azerbaijan's unwillingness to pursue economic cooperation with Armenia as long as Nagorno-Karabakh is not resolved. In the context of renewed peace efforts for this area, we and other donor nations should push for regional cooperation on matters such as water management, common customs and standards regimes to promote trade flows, and, where possible, rehabilitation of regional transport infrastructure. We also should step up our efforts to encourage Turkey, Armenia, and Azerbaijan to open their borders to spur the region's integration with the global economy, give further vitality to the "New Silk Road" linking Central Asia to the West, and enhance the region's political stability and security.

Third, efforts should begin now to ensure that revenues from the new pipelines are used in Georgia and Azerbaijan for the public good and not the corrupt few. There is ample experience from other newly-rich oil countries on how to approach this problem. The World Bank, the International Monetary Fund, and non-governmental organizations also can contribute to this task. And it is imperative that Armenia be made a full player in the energy equation to ensure its cooperation in the new emerging regional energy balance.

Finally, U.S. assistance programs in all three countries should be increased and made smarter and more focused on attacking the cancer of corruption that inhibits these states' internal development and closer relations with the United States. Congressional action to permit a presidential waiver of Section 907 of the Freedom Support Act will enhance our ability to work with all three countries on the same basis through our assistance programs to help move them toward democratic political reform and a market economy.

${ }^{22}$ Ambassador Harry Gilmore, Ambassador Richard Kauzlarich, Ambassador Kenneth Yalowitz, "Pay Attention to the South Caucasus," CSIS, January 2002, at http://www.csis. org/ruseura/caucasus/pubs/0201_sc.htm. 
More broadly, we must focus on what aid actually works and how it can be delivered even more effectively to fight corruption. There should be more emphasis on the regions and grass roots, more projects in which local communities have a stake through provision of labor and materials, more exchanges to help shape the mindset of the next generation of business and political leaders, and a readiness to reshape or stop programs if corrupt authorities hamper progress.

Since September 11, our focus correctly has been on bin Laden and the Taliban. We must not, however, lose sight of potential threats of new breeding grounds for instability, criminality, and terrorism and the need to take the necessary diplomatic, political, and assistance measures to help prevent that outcome. Those are the stakes we face today in the South Caucasus.

\section{Some Prospects for the Security Architecture in the South Caucasus}

As was mentioned earlier, with the disintegration of the Soviet Union, the Caucasus became the site for some of the most serious inter- and intra-state conflicts in the world, such as in Abkhazia, Nagorno-Karabakh, and South Ossetia. The political elites of the newly independent Caucasian states understand that their security concerns cannot be considered separately from each other, and that they contend with a pattern of ethnic conflicts that is unique to their region.

Political movements in the region have developed a radical political-propagandist rhetoric, but at the same time the various views on Caucasian unity are generally based on a kinship relation, cultural affinity, or an alliance with nations or political forces that are external to the South Caucasus region: the U.S., Russia, Turkey, Iran, the European Council, the European Union, OSCE, Euro-Atlantic Partnership Council (EAPC), or NATO.

The above-mentioned trans-regional actors have taken an interest in the Caucasus in order to meet their own security needs in unifying the Caucasus and Central Asia as a whole. Their priorities are defined by defense concerns, as well as by political and economic goals. Such an approach situates the Caucasus in a larger regional framework. Defining the region in exclusively economic terms, such as the view of the Caucasus as part of a Silk Road linking European and Asian markets, stresses the common interests of all countries but fails to address the complexity of regional integration, in which economic interests are not always predominant. One of the well-known supraregional architectural rubrics is the geopolitical frame that has Central Eurasia joining the Caspian states and the Central Asian region, an idea developed and accepted by numerous think-tanks and administrative institutions in the U.S.

All the regional actors in the South Caucasus have tried to revise the existing architecture of power distribution by forming alliances with regional and non-regional powers. Russia has been making use of its military presence in the region to establish a leading role in the South Caucasus, particularly in light of its weakness caused by its lack of ec'onomic resources and political instability in the Northern Caucasus. Azerbaijan, Georgia, and Armenia participate to different degrees in the Organization for 
Collective Security of the Commonwealth of Independent States security architecture (CIS OCS). In their moves to counterbalance the Russian presence in the region, Western states are taking advantage of their economic resources and military know-how.

But it will be impossible, even with a significantly increased Western presence in the region, to rapidly change the pattern of secessionist and ethnic conflicts in the region. The existing regional security architecture in the South Caucasus is creating a deadlock for all parties involved. Non-regional powers striving for an influential role in the region are unable to deliver sufficient assistance to secure economic development in the existing security framework. The lack of integration to a large extent is hurting their long-term economic and military strategic interests in Central Eurasia, a region that is bridged by the Caucasus.

The lack of progress in implementing the inter-governmental agreements on the establishment of transport routes and the refusal to lift existing economic blockades in the Caucasus are gravely affecting the interests of the states in the region as well as those of non-regional actors. These policies may be considered as a direct consequence of limited economic capacity due to perceived national security demands. Such a "securitization" of the national economic and political architecture of the South Caucasus has multiple effects. First, it tends to lead to a subordination of the interests of nonstate economic and political actors to local state interests. Second, a "securitization" of economic and political processes makes all types of negotiations difficult and mainly unproductive. It is not easy to accept a compromise solution when the basic interests or even the survival of the ethnic community or the state is perceived to be at stake.

Negotiations on the comprehensive and long-term resolution of secessionist conflicts in the region have to address the question of how to guarantee the reliable security of ethnic groups in the South Caucasus. The process of reformulating the security concept both for ethnic minorities and nation-states, and the integration of their economic life in the region, could be implemented by developing a three-pronged architecture of regional policy:

- Reformulation of the security concept both for ethnic groups and former Soviet colonialist "titular nations" and of the status of their legal-political coexistence as equal participants in a confederation, or in a new model of the "Common State" proposed by the Minsk Group of OSCE $;^{23}$

- Re-defining Caucasian nation-states' current security policies through intensive engagement in mutual activities within the common regional programs of OSCE and EAPC, including leading actors in the South Caucasus, the U.S., and Russia;

- Liberalization of the national economies of Caucasian nation-states from the limitations imposed by perceived difference in national security concerns by in-

${ }^{23}$ On 6 December 1994, the OSCE Budapest Summit decided to establish a co-chairmanship (shared by France, Russia, and the U.S.) for the process, thereby providing an appropriate framework for the resolution of the Karabakh conflict as a step toward assuring the negotiation process supported by the Minsk Group. 
tensifying regional economic integration within the framework of the Black Sea Economic Cooperation (BSEC), sponsored by the EU, the World Bank, the International Monetary Fund, and the World Trade Organization, and secured by a Common Architecture of Regional Security for the Caucasus established and functioning under the umbrella of OSCE, and EAPC. ${ }^{24}$

\section{Liberalization of National Economies of the Caucasian States from Limitations Imposed by Individual National Security Concerns ${ }^{25}$}

The development of multilateral regional cooperation-as a basis of economic progress, political and economic stabilization, and strengthening of neighborly relationsshould be the general objective of all regional initiatives in the Caucasus. Sponsor organizations such the EU, the World Bank, the IMF, and the WTO, as well as sponsor states, especially the U.S., ${ }^{26}$ could facilitate the process of liberalization of the national economies of the Caucasian countries based on prioritized funding of mutually developed programs for regional cooperation under the rubric of the BSEC.

Concrete economic cooperation activities are diverse, and include all issues that might be of interest to all countries in the region. With the active financial support of multinational working groups within the Black Sea Economic Cooperation framework, all of the nation-states and newly confederated ethnic entities could engage in discussions of their common economic interests, such as: telecommunications, energy, transport, infrastructure, agriculture, civil defense, migration, small enterprises, statistics, training and education, science and technology, tourism, finance, environmental protection, eradication of corruption, illegal drug trafficking and organized crime, etc.

${ }^{24}$ See Statement by the Minister of Foreign Affairs of the Republic of Armenia, 14 January 2004, at http://www.armeniaemb.org/News/Index.htm.

${ }^{25}$ The proposal is to orient the U.S. foreign policy on the prioritization of regional economic integration of the South Caucasus nations within the framework of the Black Sea Economic Cooperation (BSEC). The BSEC was founded in Istanbul on 25 June 1992 with the "Summit Declaration on Black Sea Economic Cooperation." The original signatory nations of the Black Sea Economic Cooperation accord were Albania, Armenia, Azerbaijan, Bulgaria, Georgia, Greece, Moldova, Romania, the Russian Federation, Turkey, and Ukraine. See http://www.bsec.gov.tr/.

${ }^{26}$ For example, during the past 12 years of Armenia's independence, the United States has made a concerted effort to help Armenia and the other NIS countries during their difficult transition from totalitarianism and a command economy to democracy and open markets. The cornerstone of this continuing partnership has been the Freedom for Russia and Emerging Eurasian Democracies and Open Markets (FREEDOM) Support Act, enacted in October 1992. Under this and other programs, the U.S. to date has provided nearly $\$ 1.5$ billion in humanitarian and technical assistance for Armenia. U.S. assistance programs in Armenia are described in depth on the Yerevan Embassy's website, at www.usa.am/assistance/. 


\section{Conclusion: Some Suggestions on U.S. Foreign Policy in the South Caucasus}

In conclusion, we can see that U.S. foreign policy in the region, while very supportive at present, ${ }^{27}$ would be even more effective if it placed a greater priority on the regional economic integration of the South Caucasus nations within the framework of the Black Sea Economic Cooperation accords. This approach of U.S. policy, oriented toward the intensification of regional economic integration in the South Caucasus, could be achieved only on the basis of the founding of the new architecture of common security and democracy promotion in the South Caucasus as the one holistic integrative system of foreign regional policy through the multi-partite process, interconnected by and interacting through the following elements:

- Guaranteeing the political-legal reformulation of the equal-rights relationship of the non-recognized yet already seceded ethnic entities and so-called former Soviet "titular" nations within the framework of the confederate or "common state" models oriented toward the promotion of stable economic progress and real democracy.

- Restructuring the existing security architecture in the South Caucasus within the integrative framework of OSCE and EAPC by stimulating the mutual elaboration as well as implementation by Armenia, Azerbaijan, and Georgia of the common programs on regional and Euro-Atlantic security.

- Liberalizing of the national economies of Caucasian states by targeted financial motivation of their active engagement in specifically mutual regional programs of the Organization of Black Sea Economic Cooperation, sponsored by the EU, the World Bank, the IMF, and the WTO.

- Only a system of regionally integrated programs of democracy, economy, and security development-functioning interactively both at the national and regional level-will be able to advance the regional situation from the current deadlock. U.S. foreign policy should accentuate the prioritization of such international projects specifically oriented toward the enhancement of regional and Euro-Atlantic cooperation and integration in the South Caucasus.

- The U.S. foreign policy of financial encouragement of regionally oriented cooperation among Armenia, Azerbaijan, and Georgia could launch and maintain the process of "desecuritization" of economic, legal, and political reforms, thereby advancing democracy simultaneously in these nation-states as well as in the entire region of the South Caucasus.

- The intensification of engagement of the well-organized and global Armenian Diaspora in American foreign policy could enhance its effectiveness, specifically in the South Caucasus.

${ }^{27}$ See Bureau of European and Eurasian Affairs, U.S. Department of State, March 2004, at http://www.state.gov/r/pa/ei/bgn/5275.htm. 


\section{Bibliography}

Gilmore, Ambassador Harry, Ambassador Richard Kauzlarich, and Ambassador Kenneth Yalowitz. "Pay Attention to the South Caucasus." CSIS (2002).

Kotangian, Hayk. "In Agenda: Multi-Polar and Complementary Defense Policy." Golos Armenii (2002).

Smith, Steve. "American Democracy Promotion." In US Democracy Promotion: Critical Questions. Oxford: Oxford University Press, 2000.

The Armenians in the World. (1966). 